\title{
Notes on the vocalizations of White-vented Whistler (Pachycephala homeyeri)
}

Peter Boesman

In the following we briefly analyze and compare voice of the three races of White-vented Whistler (Pachycephala homeyeri). We also try to quantify the extent of any vocal differences using the criteria proposed by Tobias et al. (2010), as a support for taxonomic review.

We have made use of sound recordings available on-line from Xeno Canto (XC) and Macaulay Library (ML).

Song of all races is a short series of melodious whistles, with many variations. A comparison of voice per race, illustrated with sonograms:

nominate (recordings of song are all from Siamil island off E Borneo)
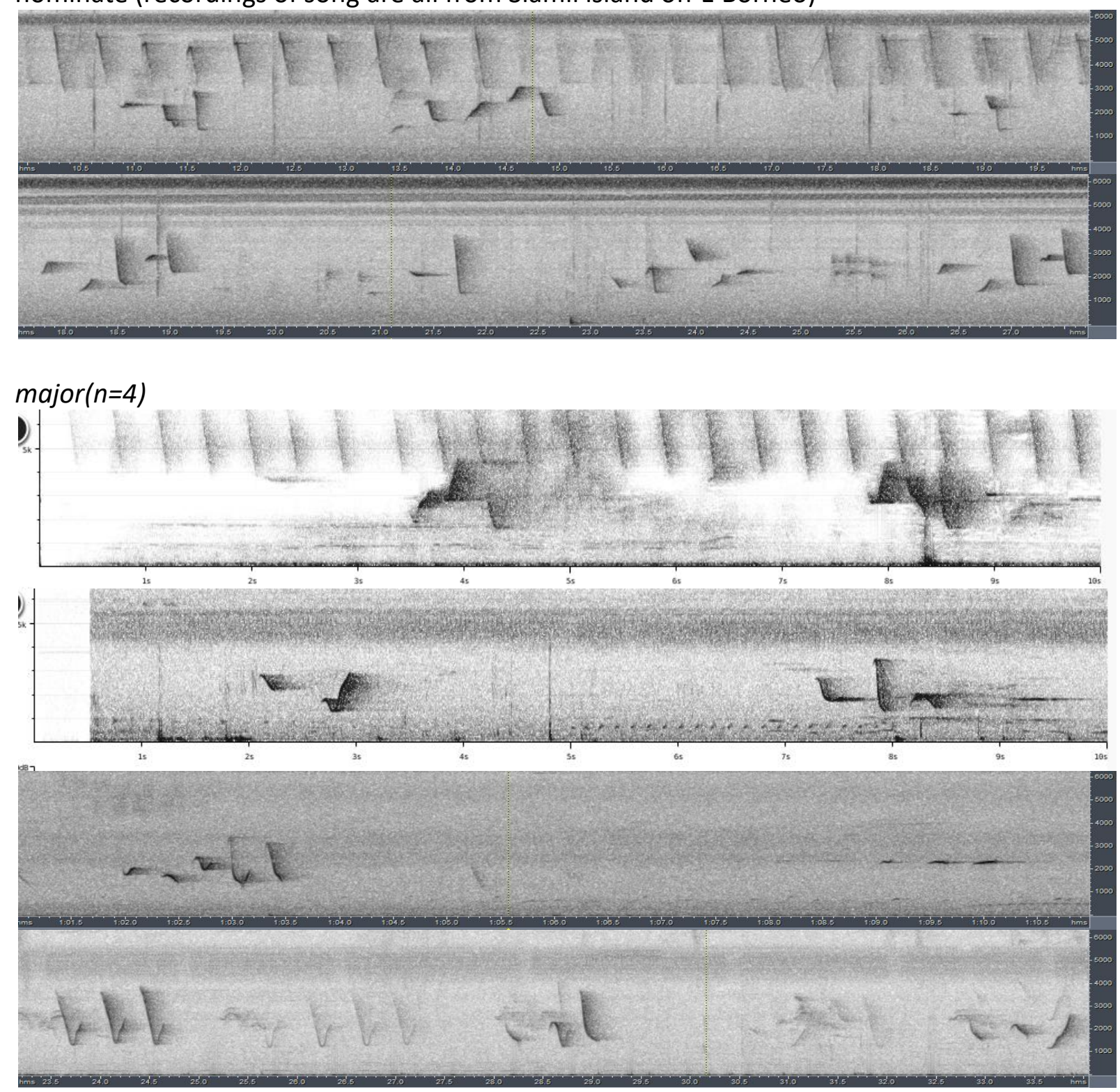

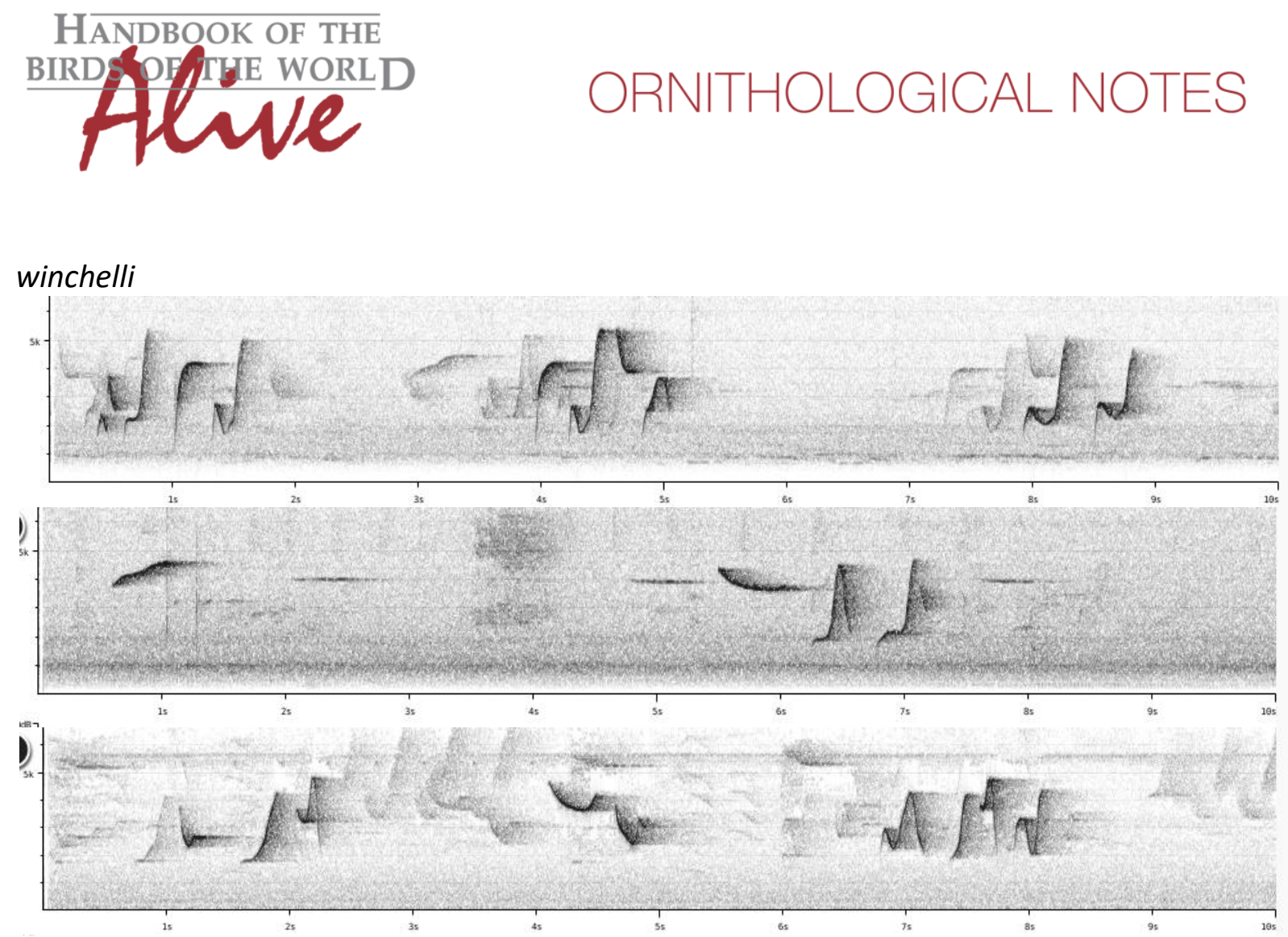

Nominate (from extreme west of its range) and major are very similar, both with many downslurred notes (all notes with largest frequency range are down-slurred).

winchelli on the contrary has a lot of upslurred notes and notes are slightly more complex in shape; maximum frequency higher (typically about $4-5 \mathrm{kHz}$ vs $3-4 \mathrm{kHz}$ typically in other races). (winchelli also seems to utter frequently a single note on even pitch, which may be an alternative song or a call, something apparently not recorded in other races)

winchelli thus seems to be vocally the most distinctive taxon, although some caution is needed given the small sample size and absence of recordings from S Philippines.

This note was finalized on 15th March 2016, using sound recordings available on-line at that moment. We would like to thank in particular the sound recordists who placed their recordings for this species on XC and ML: Desmond Allen, Stijn de Win, Justin Hite, Peter Hosner, Martin Kennewell, Frank Lambert and Ding Li Yong.

\section{References}

Tobias, J.A., Seddon, N., Spottiswoode, C.N., Pilgrim, J.D., Fishpool, L.D.C. \& Collar, N.J. (2010). Quantitative criteria for species delimitation. Ibis 152(4): 724-746.

\section{Recommended citation}

Boesman, P. (2016). Notes on the vocalizations of White-vented Whistler (Pachycephala homeyeri). HBW Alive Ornithological Note 432. In: Handbook of the Birds of the World Alive. Lynx Edicions, Barcelona. (retrieved from http://www.hbw.com/node/1275499 on 8 December 2016). 